\title{
Donald Trump's Muslim Banning in Two Mic's Articles: A Transitivity Analysis Rifah
}

\author{
Ika Yatmikasari
}

\begin{abstract}
Muslim banning issued by Donald Trump in his early presidency has become a controversial policy in US. It triggers various reaction both on the street and in the media. Mic of US is one of them that provide citizen's opinion on the issue. This study aims at revealing the writers of two Mic articles' view on Donald Trump and on the issue related to Muslim banning itself by means of transitivity analysis, one metafunction in Systemic Functional Grammar. It also observes the different view (if any) between the two articles on the person and the issue they discuss. The analysis on process types and circumstances of the clauses in both articles results in: the writer's disagreement and dislike on Donald Trump and the policy in the article entitled Can Donald Trump ban all Muslims? Here's what to know about his awful proposition; and the writer's support on Donald Trump and the issue in the second article entitled Donald Trump Calls for "A Total and Complete Shutdown" of Muslims Entering the US.
\end{abstract}

Keyword: transitivity, process, circumstance, muslim banning

\section{Introduction}

American national election that was held on $8^{\text {th }}$ November 2016 cannot be separated from the one controversial candidate, Donald Trump. Born in New York City $14^{\text {th }}$ June 1946, Trump has become the most successful entrepreneur, businessman, and television program pioneer. He was the leader of Trump Organization in 1971 and the presenter of NBC "The Apprentice" reality show. $\mathrm{He}$ was known as an outspoken and glamorous person in living his life. In 2010, Trump declared that he is interested in joining American presidential candidate for 2012 election. One year after the declaration, he changed his interest to the election 2016 then some weeks later he declared again to join American presidential election. Trump won the Republic Convention Party 19 $9^{\text {th }}$ July 2016 by defeating Ted Cruz exceeding the minimum vote result. Within four months road to US national election in November, Trump announced some programs and ideas to his next presidential that has been started in November 2016, gaining various feedback from the society.

Since his declaration as one of US presidential candidate, Trump stated several controversial issues in his campaign which was claimed as his program for his leadership. The most controversial issue was that he would ban all the Muslim immigrants to U.S. who 
come around December until the preparation to the US presidential election. He stated it at his campaign office in New Hampshire that has been spread in a twominute duration video. After he won the presidential election, defeated Hillary Clinton, Trump has really realized his program. All media either mass media or television reported his statement, including Mic.

Mic is an American website that is active in releasing news and articles on the issue happening around the globe. Regarding Trump's Muslim banning, there are two articles in this website to analyze. The first entitles "Can Donald Trump ban all Muslim? Here's what to know about his awful proposition" by Claire Lampen, and the second "Donald Trump calls for 'A Total and Complete Shutdown' of Muslim entering the U.S” by Scott Bixby. The two articles were chosen as they purely contains the writers' view and opinion, not reporting news.

In order to know what the writers' view actually is, Transitivity system is applied to analyze the clauses by finding out the process types and circumstances (Halliday, 2014). Transitivity is one metafunction in Systemic Functional Linguistics (SFL) that shows how experience is represented according to reality that occurs in environment and their mind. The experience itself is realized by processes in clauses which fall into the processes of doing, feeling, being, and happening (Halliday, 1985).

By means of Transitivity analysis and by employing qualitative method, this study is aimed at finding the answers for the following questions: 1) How is the writer's view on Donald Trump related to the issue of Muslim banning represented in the choice of process types and circumstances?; 2) How is the writer's view of Donald Trump's statement on the issue itself?; and 3) Is there any differences between the two articles on the person and issue they discuss? The answers to these questions are discussed in the body section of this paper.

\section{Transitivity}

Transitivity is the grammatical function of clause as representation in Systemic Functional Grammar. It is used as the tool to disclose events which lie in the clause (Halliday, 1994). In Transitivity, clause is the realization of ideational meaning, it is the meaning represented through a set of experience as well as a state of being that occurs in the world and their mind. Furthermore, clause as representation describes how experience is presented in the through its process that constructs the meaning, undertaken by the actor that has the 
experience as an active participant in that process (Halliday, 2014: 211). It further explains that clauses in this system is divided into three elements of semantic

categories, they are processes, participants, and circumstances (Gerot \& Wignell,

1995:

52).

Processes represent the flow of events or ongoing human activities (Halliday \& Matthiessen, 2014: 300). All clauses will contain one of the following processes; they are the process of happening, doing, sensing, saying, being, and having (Halliday \& Matthiessen, 2014: 211). These processes are named as material, mental, verbal, behavioral, relational, and existential processes (Halliday 2014: 213). Each process has its typical participants, while circumstances carry adverbial structure in formal grammar and are applicable to the whole processes.

\begin{tabular}{|c|c|c|c|}
\hline Participants & Processes & Participants & Examples \\
\hline $\begin{array}{l}\text { Actor } \\
\text { Initiator }\end{array}$ & Material & $\begin{array}{l}\text { Goal } \\
\text { Range } \\
\text { Beneficiary - Client } \\
\text { Beneficiary - Recipient }\end{array}$ & $\begin{array}{l}\text { I' (A) } \mathrm{m} \text { following } \\
\text { your way (R). } \\
\text { Blinding hail (Int.) } \\
\text { caused (Pr: Mt) him } \\
\text { (G) to swerve (Pr: } \\
\text { Mt) off the road. } \\
\text { He bought a house } \\
\text { for his parents (C). } \\
\text { They sold the old } \\
\text { house to a stranger } \\
\text { (R). }\end{array}$ \\
\hline $\begin{array}{l}\text { Senser } \\
\text { Inducer }\end{array}$ & Mental & Range/ Phenomenon & $\begin{array}{l}\text { I would remember } \\
\text { his words }(\mathrm{P}) \text {. } \\
\text { The fact bothers me } \\
\text { (P). } \\
\text { It }(\mathrm{P}) \text { suprises me } \\
\text { that she won }(\mathrm{P}) \text {. } \\
\text { She (Ind.) made her } \\
\text { (S) feel sorry. }\end{array}$ \\
\hline Behaver & Behavioral & $\begin{array}{l}\text { Range/ } \\
\text { Phenomenon }\end{array}$ & $\begin{array}{l}\text { She smiles a broad } \\
\text { smile }(\mathrm{B}) \text {. } \\
\text { She sniffed the soup } \\
(\mathrm{P}) \text {. }\end{array}$ \\
\hline \multirow[t]{2}{*}{ Sayer } & Verbal & $\begin{array}{l}\text { Target } \\
\text { Receiver } \\
\text { Range/ Verbiage }\end{array}$ & 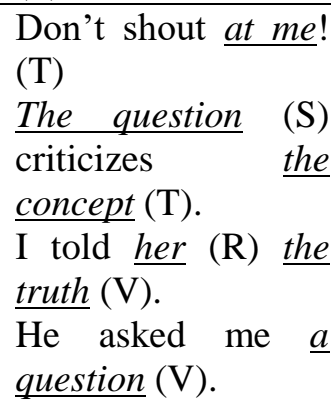 \\
\hline & Existential & Existent & $\begin{array}{l}\text { There is something } \\
\text { (E) about Mary. }\end{array}$ \\
\hline
\end{tabular}


Jurnal al-Tsaqafa Volume 15, No. 01, Juli 2018

\begin{tabular}{|l|l|l|l|}
\hline Atrributor Assigner & $\begin{array}{l}\text { Relational (additional } \\
\text { participants) }\end{array}$ & $\begin{array}{l}\text { Carrier } \\
\text { Attributive }\end{array}$ & $\begin{array}{l}\text { He (Atr) made (Pr: } \\
\text { int-att) her (Cr) a } \\
\text { fool (Att). } \\
\text { He (Atr) made (Pr: } \\
\text { int-att) her (Cr) a } \\
\text { fool (Att). }\end{array}$ \\
\hline
\end{tabular}

Table 1. Participants for each process

The table above demonstrates two structural categories of Transitivity: process and participant, in which particular participants only appear for particular process type.

\begin{tabular}{|l|l|l|}
\hline Circumstances & \multicolumn{1}{|c|}{$\begin{array}{c}\text { Sub- } \\
\text { categories }\end{array}$} & \\
\hline \multirow{3}{*}{ Enhancing } & Time & The 2008 Olympic Games will be officially opened on August 8. \\
\cline { 2 - 3 } & Place & It will be held in Beijing. \\
\hline & Duration & She drinks every three hours. \\
\cline { 2 - 3 } & Distance & It is almost 450 kilometres from Bandung to Jogja. \\
\cline { 2 - 3 } & Manner & Athletes will be taken to the games venues by all kinds of transportation means. \\
\cline { 2 - 3 } & Cause & China is protested for its human rights violations in Tibet. \\
\hline Contingency & Despite the rain comes down, he will never stop. \\
\hline Extending & I come without him. \\
\hline Elaborating & The cassava is processed become floor. \\
\hline \multicolumn{2}{|l|}{ Projection } & She talks about the expansion of England. \\
\hline
\end{tabular}

Table 2. Circumstantial elements 
Meanwhile, this table contains the remaining category of Transitivity namely circumstance. It serves the function of adverbial in a clause thus the position is relatively free and its existance is not affected by process type.

\section{The Writers' View on Donald Trump}

to disclose the writers' view, transitivity is applied by analysing each clause in each article and observing its indication through the use of particular process types amd circumstances. Some samples of the analysis in article 1 is presented as follows:

(Line 1-3)

In electing Donald Trump to the presidency, Americans effectively endorsed a ban on Muslims entering the United States-a promise the former businessman made repeatedly over the course of his campaign (Lampen, 2015).

\begin{tabular}{|c|c|c|}
\hline $\begin{array}{c}\text { In electing DT to } \\
\text { the presidency, }\end{array}$ & Americans & effectively \\
\hline $\begin{array}{c}\text { Circumstance: } \\
\text { cause }\end{array}$ & Actor & $\begin{array}{c}\text { Circ. } \\
\text { manner }\end{array}$ \\
\hline
\end{tabular}

\begin{tabular}{|l|c|c|}
\hline endorsed & a ban & $\begin{array}{c}\text { on Muslims entering } \\
\text { the United States }\end{array}$ \\
\hline $\begin{array}{l}\text { Process: } \\
\text { material }\end{array}$ & Goal & $\begin{array}{c}\text { Circumstance: } \\
\text { projection }\end{array}$ \\
\hline
\end{tabular}

The process used in the clause above is material process. The verb "endorsed" as the process of material shows the action that is done by the actor. The verb has meaning of approval or support for something. The circumstance of cause indicates the cause of process is "In electing DT to the presidency" which refers to the condition where Donald Trump has been chosen as the president by American people. The circumstance of manner "effectively" describes how the process is actualized. It means in a way of what is been achieved. The circumstance of projection is the matter of what the matter is being discussed or about what the process is talked about. It refers to Trump's statement on Muslim banning to US. The process also shows a goal that is "a ban".

It can be concluded from the circumstances and process used in the clause is that in electing Donald Trump as the new president of America, American people at the same time effectively supported his policy of Muslim banning in America. Meanwhile, the circumstance is used to show the writer's indirect writer's disagreement to the American society about Trump's statement on Muslim banning. The writer's disagreement to the American society also shows indirectly a disagreement to Donald Trump in becoming the new US president.

\section{(Line 13-14)}

In a press release sent, Trump announced that he is called for a "total and complete shutdown" of immigration by Muslims into the United States (Bixby, 2016).

\begin{tabular}{|c|c|c|c|}
\hline $\begin{array}{c}\text { In a press } \\
\text { release } \\
\text { sent, }\end{array}$ & Trump & announced & that \\
\hline
\end{tabular}




\begin{tabular}{|c|c|c|c|}
\hline Cir: extent & Sayer & $\begin{array}{c}\text { Process: } \\
\text { verbal }\end{array}$ & - \\
\hline
\end{tabular}

\begin{tabular}{|c|c|c|}
\hline he & is called for & $\begin{array}{c}\text { a "total and complete } \\
\text { shutdown" }\end{array}$ \\
\hline Sayer & Process: verbal & Verbiage \\
\hline \multicolumn{3}{|c|}{ Verbiage } \\
\hline
\end{tabular}

of immigration by Muslims into the United States Circumstance: projection

The clause above shows the verbal process which is reported by the sayer. This clause indicates that Trump announced in a press release that he is called the issue for a total and complete shutdown of immigration which is done by Muslims into United States. This clause serves the verb "announced" as the process to show that Trump states or makes the public to know his statement in stopping totally the operation of immigration by Muslims into United States. The verbiage in this clause uses the citation which has been stated by Trump to describe the verbalization than using any noun.

The verbiage in this clause also can be divided into sayer, verbal process, and verbiage. It shows that the verbiage also contains the activity by Trump as the sayer who "called for" or demands a total and complete shutdown of Muslims.

In the circumstance of projection, it contains "immigration by Muslims" not only Muslims. It indicates the writer wants to show that Muslims also did the activity that causing the ban.

In conclusion, this clause is the complement of the previous clause which is addressed by Trump that the two alleged attackers in San Bernardino mass shooting were encouraged to do so, if not mentally supported, it might be supported materially by the Islamic State militant group. The clause shows that the process mentioned is scatologically concise or it means Trump addressed the fact and expressing it that shows he has unpleasant interest about it. This process also might indicates that the writer wants to show Trump's dislike regarding on San Bernardino mass shooting which probably materially supported by the Islamic state militant group.

Based on the explanation above, the writer often uses verbal process to show the verbal activity that is spoken by Trump. The writer uses this kind of process to show every statement that links to his statement related to Muslims banning to US.

In conclusion, this clause is the complement of the previous clause which is addressed by Trump that the two alleged attackers in San Bernardino mass shooting were encouraged to do so, if not mentally supported, it might be supported materially by the Islamic State militant group. The clause shows that the process mentioned is scatologically concise or it means Trump addressed the fact and expressing it that shows he has unpleasant interest about it. This process also might indicates that the writer wants to show Trump's dislike regarding on San Bernardino mass shooting which probably 
materially supported by the Islamic state militant group.

Based on the explanation above, the writer often uses verbal process to show the verbal activity that is spoken by Trump. The writer uses this kind of process to show every statement that links to his statement related to Muslims banning to US.

Thus, from the verbal process which is used by the writer indicates Trump as the one who reported and did verbal action in a good way. Whereas, in material clause, the writer places Trump in the circumstance of projection as the complement and to show his belief on Trump as the new president of America. It can be concluded that the writer supports Trump related to the Muslim banning issue to the US. The writer sees Trump did not do any wrong action but a good thing.

The Writer's View on the Issue of Muslim

\begin{tabular}{|c|c|c|}
\hline $\begin{array}{c}3.3 \text { million } \\
\text { Muslims }\end{array}$ & lived & in the U.S \\
\hline Actor & $\begin{array}{c}\text { Process: } \\
\text { material }\end{array}$ & $\begin{array}{c}\text { Circumstance: } \\
\text { location }\end{array}$ \\
\hline
\end{tabular}

\section{Banning}

Transitivity analysis in this section is focused on the topic of Muslim Banning itself through the use of particular process type. The analysis will lead to the result which answers the second research question.

(Line 4-5)
The Pew Research Center estimated that as 2015 roughly 3.3 million Muslims lived in the U.S (Lampen, 2015).

\begin{tabular}{|c|c|c|c|}
\hline $\begin{array}{c}\text { The Pew } \\
\text { Research } \\
\text { Center }\end{array}$ & estimated & $\begin{array}{c}\text { that as } \\
2015\end{array}$ & roughly \\
\hline Senser & $\begin{array}{c}\text { Pr: } \\
\text { mental }\end{array}$ & $\begin{array}{c}\text { Cir: } \\
\text { extent }\end{array}$ & $\begin{array}{c}\text { Cir: } \\
\text { manner }\end{array}$ \\
\hline
\end{tabular}

The clause above indicates mental process by the verb "estimated". The participant which involve in this clause are "The Pew Research Center" as the senser. This mental process shows of what the senser thought. The senser does the activity which is done in his mental or cognition. This clause shows that the senser estimates of something. The verb "estimates" indicates on how person guess a calculation of population or statistic. The circumstance of extent and location show that the senser guess the statistic which happened in 2015. The word "roughly" indicates the approximately of statistic amount.

To sum up, the clause above indicates that the mental process has purpose to show that the subject or the senser estimates the calculation of statistic which the amount is closely to the real number in reality.

The clause above contains material process with the verb "lived". The actor in this clause is " 3.3 million Muslims". This actor shows of a big amount that lived in the U.S. The circumstance in this clause is "in the U.S" 
which indicates the location of where the actor lived. The verb "lived" includes into past form which indicates that the actor lived in the U.S for a long time ago. So that 3.3 million Muslims lived in the U.S for a long time. The amount that is served by the writer to describe people that is forbidden and devastated is a big numbers.

\section{(Line 29-30)}

There is the Chinese Exclusion Act of 1882 which halted emigration from China to the US for a decade and barred Chinese people from becoming US citizen (Lampen, 2015).

\begin{tabular}{|c|c|c|c|}
\hline There & is & $\begin{array}{c}\text { the Chinese } \\
\text { Exclusion Act }\end{array}$ & $\begin{array}{c}\text { of } \\
1882\end{array}$ \\
\hline- & $\begin{array}{c}\text { Pr: } \\
\text { existential }\end{array}$ & Extent & $\begin{array}{c}\text { Cir: } \\
\text { extent }\end{array}$ \\
\hline
\end{tabular}

The clause above shows the existential process with the verb "is" namely be. The verb purposes to indicate the existential of "the Chinese Exclusion Act" as the extent which happened in 1882 .

(Line 28-31)

"The statement cites a poll conducted by the Center for Security Policy, a Washington, D.C.based think tank based frequently accused of propagating conspiracy theories, which purports to demonstrate that $25 \%$ of American Muslims agree that violence against Americans is "justified as a part of the global jihad." " (Bixby, 2016)

\begin{tabular}{|c|c|c|c|}
\hline $\begin{array}{c}\text { The } \\
\text { statemen } \\
t\end{array}$ & cites & a poll & $\begin{array}{c}\text { conducted by } \\
\text { the Center for } \\
\text { Security Policy }\end{array}$ \\
\hline Sayer & $\begin{array}{c}\text { Pr: } \\
\text { verba } \\
\mathbf{l}\end{array}$ & $\begin{array}{c}\text { Verbiag } \\
\text { e }\end{array}$ & $\begin{array}{c}\text { Circumstance } \\
\text { : extending }\end{array}$ \\
\hline
\end{tabular}

The clause above indicates the verbal process. The verb "cites" shows the process of saying whether it is written or verbal. This verb in this clause indicates to mention a theory or a proof or a reason why something is happened. The sayer in this clause is "the statement" which does the verbalization. It refers to the Trump's statement about Muslim banning to U.S in his campaign. The verbiage or the verbalization in this clause is "a poll" which is cited by Trump in his campaign as a proof or reason of his statement. Meanwhile, the circumstance of extending in this clause is "conducted by the Center for Security Policy" which is explained by whom the poll is conducted. In conclusion, this clause indicates the Trump's statement in his campaign about Muslim banning to US cites the poll which is conducted by the Center for Security Poll. It means the process shows of a proof to strengthen the statement to public.

\begin{tabular}{|c|c|c|c|}
\hline $\begin{array}{c}\text { a } \\
\text { Washington } \\
\begin{array}{c}\text { D.C.-based } \\
\text { think tank } \\
\text { based }\end{array}\end{array}$ & frequently & accused & $\begin{array}{c}\text { of } \\
\text { propagating } \\
\text { conspiracy } \\
\text { theories }\end{array}$ \\
\hline Sayer & $\begin{array}{c}\text { Cir: } \\
\text { manner }\end{array}$ & $\begin{array}{c}\text { Process: } \\
\text { verbal }\end{array}$ & $\begin{array}{c}\text { Cir: } \\
\text { projection }\end{array}$ \\
\hline
\end{tabular}

The clause above indicates the verbal process. The verb "accused" shows the process of saying. The verb means to say that someone has done something morally wrong or unkind (Cambridge, 2008). It is also the past form verb which indicates that the activity has done in the past. The sayer in this clause is "a Washington D.C.-based think tank based" who reported the verbalization. It refers to the group who discuss, think, and write about the solution of the problems in society. In 
America, there are many think tank based which discusses the problem of humanity, which is described in the previous clause that is Center for Security Policy. The circumstance of manner is "frequently" indicates how the process is actualized. It shows that the process is done often. Another circumstance in this clause is projection which is "of propagating conspiracy theories" which indicates the matter being discussed in this clause. It refers to the theory about the propagating conspiracy which is believed exist in Islam.

\section{The Difference between the Two Articles on}

\section{the Person and the Issue}

The analysis and interpretation in the first and second section has provided the result of the writer's view on Donald Trump related to the issue of Muslim banning. After all the results have been achieved by the researcher, it can be concluded that the two articles have differences. In the articles "Can Donald Trump ban all Muslims? Here's what to know about his awful prepositions" by Claire Lampen, the writer does not support and put any sympathy to Donald Trump. It can be proven that in the article, the writer uses material process dominantly to present Trump in the sentence or clause. The writer uses material clauses to describe Donald Trump as the actor or the main subject in doing the action. Meanwhile, Muslim and anything that link to them is always put as the object or the goal. It can be concluded that the writer views Donald Trump as the main subject who does all the action which is harshly pointed to Muslim. In other words, the writer sees Muslims as the victim of what Trump has been doing. The processes which are used in the article also have intention to serve foul action by Trump. The writer also frequently uses connotation phrases to show the disagreement.

Meanwhile, in the article "Donald Trump Calls for "A Total and Complete Shutdown" of Muslims Entering the US" by Scott Bixby, the writer shows his agreement on Donald Trump's policy of banning Muslim from certain countries to come to his country. The writer often uses verbal clauses with polite verb to show his agreement and respect for Trump related to the issue.

After all the result has been achieved, it can be concluded that the two articles have contradictive tendency. In the first article by Claire Lampen, the writer puts emphasis more on the issue rather than Donald Trump itself. In presenting the issue in the clauses, the writer often uses attributive intensive clausess to show his disagreement on the issue itself.

Similar to that, the article "Donald Trump Calls for "A Total and Complete Shutdown" of Muslims Entering the US" by Scott Bixby talked about the issue itself than the person. The writer provides the issue in sentence or clause with statistic and poll which 
is issued by Washington D.C-based think tank. It describes that the poll said of $25 \%$ of American Muslims agree that violence against American is justified as a part of the global jihad and $51 \%$ of those polls agreed that Muslims in America should have the choice being governed according to shariah (law). Those sentences or clauses is served by the writer by using material and verbal clause to show the proof and strengthen Donald Trump's statement in banning Muslims.

\section{Conclusion}

After analyzing and interpreting the clauses or sentences in the two articles, most of process type which is used is material process. Each process and circumstance which is used by the writer in each sentence or clause has intention to show how the writer represents the events according to what they sense of, thought of, happening in, doing in, and related to. Each article has its meaning and purpose to show the writer's view on the person (Donald Trump) and the issue itself. the result of the first research problem shows that the first article indicates the writer's disagreement to Donald Trump in relation to the issue of Muslim banning. The writer represents his disagreement by the choice of process type which is material process that can affect the position of the participant, meanwhile the circumstance which is used in the article is to describe how the time, place, and other adverbial to complement the process and the participant. It can be seen from the process which is used by the writer in this article which shows disagreement harsh process in describing Trump's action as the main subject to Muslims as the object. In contrast, the second article shows the writer's support or agreement to the person (Donald Trump) which is similarly indicated by the use of process type and circumstance. The type of process in this article varies but still describe the writer's view on the person and the issue. The process which is used by the writer in this article is delivered in polite ways and the circumstance which is used mostly shows to describe his agreement on Donald Trump and the issue.

\section{References}

Gerot, L. \& Wignell, P. 1995. Making Sense of

Functional Grammar. Sydney: Gerd Stabler.

Halliday, M.A.K. 1985. An Introduction to Functional Grammar. London: Edward Arnold.

Halliday, M.A.K \& Mathiessen, C. 1994.

Halliday, M.A.K. 1994. Introduction to Functional Grammar. New York: Routledge.

Halliday, M.A.K. 2014. Introduction to Functional Grammar. London: Edward Arnold. 